\title{
PENYUSUNAN DAN PENYAJIAN LAPORAN KEUANGAN DI LEMBAGA KEUANGAN SYARIAH
}

\author{
Himyar Pasrizal' ${ }^{1}$, Fajrur Rahmi ${ }^{2}$ \\ Corresponding Author's : Institut Agama Islam Negeri Batusangkar \\ Email : himyar.pasrizal@iainbatusangkar.ac.id \\ Copyright (C) 2021 \\ atoen
}

\begin{abstract}
The purpose of this study is to provide knowledge on the preparation and position of each item contained in the transaction report on sources and uses of qardhul hasan fund and financial report on sources and zakat fund. The research method in this article is descriptive qualitative research by analyzing the two types of financial statement in islamic financial institution. The result in this study are the source and us of qardhul hasan fund in islamic financial institution sourced from infaq fund, alms, and result from the management of waqf fund and non halal income fund. Meanwile in the financial statement, the sources and uses of zakat fund come from zakat fund obtained from internal parties of islamic financial institution and external parties, namely people who are not customer of islamic financial instutions.
\end{abstract}

Keywords: Penyusunan, Penyajian, Laporan Keuangan, Keuangan Syariah

\section{PENDAHULUAN}

Bank menurut Ismail dalam Giri (2016), yaitu lembaga keuangan yang memiliki fungsi utama yaitu melakukan penghimpunan dana dari masyarakat kemudian disalurkan kembali kepada masyarakat yang membutuhkan dana serta memberika pelayanan jasa dalam lalu lintas pembayaran. (Agil and Giri 2016). Bank di Indonesia berdasarkan prinsip operasionalnya ada dua, yaitu bank konvensional atau bank komersil dan bank syari’ah. Bank konvensional yaitu lembaga keuangan yang melakukan aktifitas keuangan dengan sistem bunga. Adapun konvensional ini terdiri dari Bank Umum Konvensional dan Bank Perkreditan Rakyat.
Sementara itu Bank Syari'ah adalah bank yang melakukan aktifitas keuangan di Bank syari`ah dengan berlandaskan kepada prinsip syari`ah. Bank syari`ah di Indonesia terdiri dari Bank Umum Syari`ah dan Bank Pembiayaan Rakyat Syari'ah (Amah 2013).

Baik Lembaga keuangan konvensional ataupun lembaga keuangan syari`ah, kinerja keuangan setiap lembaga akan terlihat dari laporan keuangan. Laporan keuangan merupakan media yang digunakan untuk melakukan penelitian terhadap kondisi kesehatan perusahaan yang terdiri dari neraca, perhitungan laba rugi, laba yang ditahan serta laporan lainnya. Tujuan 
adanya laporan keuangan disetiap lembaga keuangan yaitu memberikan posisi kinerja dan arus kas yang bermanfaat bagi sebagian besar masyarakat yang menggunakan laporan keuangan untuk melihat serta mengambil keputusan-keputusan dan pertanggungjawaban dari pihak manajemen (Fajarwati 2010).

Laporan keuangan yang ada di lembaga keuangan konvensional dan lembaga keuangan syariah memiliki perbedaan antara jenis laporan keuangan. Dimana pada Lembaga keuangan syari'ah, terdapat laporan keuangan khusus yang menjadi ditampilkan di laporan keuangan di lembaga keuangan syari’ah. Dimana di Lembaga Keuangan Syariah terdapat laporan dalam mengelola dana qardhul hasan serta laporan pengelolaan dana zakat (Ilyas 2016). Sebagaimana diketahui bahwa penggunaan laporan qardhul hasan serta laporan pengelolaan dana zakat sama-sama memiliki tujuan yang sama yaitu untuk tujuan sosial (Kadarningsih 2017). Namun pengelompokkan dana ini tidak di akumulasi dalam satu bentuk laporan keuangan. Untuk itu, penulis akan menjelaskan serta menganalisis bentuk penyusunan dan penyajian laporan keuangan sumber dan penggunaan dana qardhul hasan serta laporan sumber dan penggunaan dana zakat.

\section{KAJIAN TEORI}

\section{Laporan Keuangan}

Laporan Keuangan merupakan akhir dari proses akuntansi dimana dalam proses tersebut semua transaksi yang terjadi akan dicatat, diklasifikasikan, diikhtisarkan untuk kemudian disusun menjadi suatu laporan keuangan. Sementara itu menurut Standar Akuntansi keuangan mengemukakan bahwa laporan keuangan merupakan bagian dari proses laporan keuangan dimana laporan keuangan tersebut biasanya meliputi neraca, laporan laba rugi, laporan perubahan posisi keuangan (yang disajikan dalam berbagai cara, misalnya sebagai laporan arus kas, atau laporan arus dana) dan laporan lainnya serta penjelasan yang merupakan bagian integral dari laporan keuangan. (Matnin 2016).

Selain itu juga terdapat definisi laporan keuangan mengemukakan metode yang dipakai untuk meneliti kondisi kesehatan perusahaan yang terdiri atas neraca, perhitungan laba rugi, ikhtisar laba yang ditahan dan dilaporan posisi keuangan. Sebagaimana diketahui bahwa laporan keuangan pada prinsipnya merupakan salah satu pertanggungjawaban manajemen atas sumber daya yang dipercayakan kepadanya. Oleh karena itu, laporan keuangan dapat dijadikan sebagai sumber informasi utama oleh berbagai pihak untuk menilai kinerja manajemen sekaligur kinerja ekonomi perusahaan. (Putri, Jonathan, and Lau 1998).

Berdasarkan definisi di atas, dalam hal ini penulis memberikan simpulan terhadap definisi laporan keuangan tersebut yaitu informasi yang disajikan atas akumulai transaksi yang telah dilaksanakan oleh suatu perusahaan dalam satu periode serta digunakan 
untuk pengambilan keputusan bagi perusahaan untuk periode yang akan datang.

Pernyataan Standar Akuntansi Keuangan 101 Penyajian Laporan Keuangan Syariah (selanjutnya disebut PSAK 101) menetapkan dasar penyajian laporan keuangan bertujuan umum untuk entitas syariah. Pernyataan ini mengatur persyaratan penyajian laporan keuangan, struktur laporan keuangan, dan persyaratan minimal isi laporan keuangan atas transaksi syariah.

\section{Laporan Keuangan Perbankan Syariah}

\section{Laporan Neraca}

Setiap item yang terdapat pada laporan neraca di Perbankan Syari'ah meliputi aktiva, liabilitas, investasi tidak terikat serta modal atau ekuitas. Penyajian aset pada neraca atau pengungkapan pada catatan atas laporan keuangan atas aset dibiayai oleh bank sendiri dan aset yang dibiayai oleh bank bersama pemilik dana investasi tidak terikat, laporan ini dilakukan secara terpisah.

\section{Laporan Laba Rugi}

Laporan laba rugi merupakan laporan yang menyajikan informasi keuangan untuk mengetahui apakah lembaga keuangan mengalami keuntungan ataupun kerugian. Hal ini diketahui dari informasi penggunaan pendapatan dan beban selama satu periode tertentu. Lembaga keuangan mendapatkan keuntungan jika pendapatan diperoleh melebihi dari nilai beban. Namun sebaliknya lembaga keuangan akan mengalami kerugian jika kelompok beban lebih besar daripada pendapatan dalam periode tertentu (Nandasari 2014)

\section{Laporan Arus Kas}

Laporan arus kas memiliki fungsi dalam menginformasikan kemampuan perusahaan dalam menghasilkan kas setara kas serta melakukan penilaian terhadap kebutuhan perusahaan yang dilakukan dengan menggunakan dana kas. (Nandasari 2014)

\section{Laporan Perubahan Ekuitas}

Laporan ini merupakan ikthtisar dari perubahan pemilik yang terjadi selama periode tertentu. Perubahan ekuitas bank syariah ini menggambarkan peningkatan atau penurunan aset bersih atau kekayaan selama periode bersangkutan berdasarkan prinsipprinsip pengukuran tertentu yang dianut dan harus diungkapkan dalam laporan keuangan. Komponen yang ada pada laporan keuangan perubahan ekuitas ini antara lain yaitu: (Sutarti, Tachyan, and Saesar 2012)

a. Informasi tentang laba rugi bersih selama periode tertentu

b. Informasi tentang jumlah pendapatan dan laba serta keuntungan dan kerugian diakui secara langsung dalam ekuitas

c. Informasi yang berhubungan dengan transaksi modal antara pemilik dengan pendistribusi kepada pemilik.

d. Adanya informasi saldo pengelompokan dari laba rugi di awal dan di akhir periode serta jika ada modifikasi

Selain itu juga ada rekonsiliasi nilai dari jenis modal saham, agio serta cadangan di awal dan di akhir periode. 


\section{Laporan Perubahan Dana Investasi} Terikat

Laporan perubahan dana investasi terikat di Bank Syari'ah yaitu dana yang berasal dari pemilik dana investasi terikat dan sejenisnya kemudian dikelola oleh bank syari'ah dalam hal ini bank diibaratkan sebagai perantara dalam melaksanakan investasi. Investasi terikat ini bukan dikategorikan sebagai aset ataupun kewajiban, hal ini dikarenakan bahwa bank syari’ah tidak memiliki hak untuk menggunakan ataupun mengeluarkan dana investasi ini, selain itu bank syari'ah juga tidak memiliki kewajiban untuk mengembalikan atau menanggung risiko investasi.

Adapun keuntungan serta kerugian pada investasi terikat ini merupakan jumlah kenaikan ataupun penurunan bersih nilai investasi terikat, selain kenaikan yang bersumber dari penyetoran ataupun penurunan yang berasal dari penarikan. Sebagai agen investasi, bank syari ah akan menerima imbalan yang diterima yaitu sebesar jumlah yang disepakati tanpa memperhatikan hasil dari investasi. (Suharto 2020)

\section{Laporan Sumber dan Penggunaan Dana Qardhul Hasan}

Qardhul hasan secara terminologi menurut Dewan Syariah Nasional dalam Kadarnangsih dkk (2017) memiliki arti sebagai suatu pinjaman dana tanpa adanya tambahan yang diberikan disaat pengembalian oleh peminjam untuk menggunakannya selama jangka waktu tertentu dan akan mengembalikan dalam jumlah yang sama pada akhir periode setelah disepakati tanpa memberikan kelebihan (Kadarningsih 2017). Dana kebajikan merupakan dana sosial diluar zakat yang berasal dari masyarakat yang dikelola oleh bank syari`ah. Dana kebajikan ini biasanya disebut dengan dana qardh. Sumber dana kebajikan ini terdiri dari infak, sedekah hasiil pengelolaan wakaf sesuai dengan perundangan yang berlaku, pengembalian dana kebajikan produktif, denda, pendapatan non halal, serta sumbangan/hibah. Dana kebajikan ini digunakan untuk dana kebajikan produktif, sumbangan dan penggunaan lainnya untuk kepentingan umum (Suharto 2020)

\section{Laporan Sumber dan Penggunaan Dana Zakat}

Zakat merupakan sebagian harta yang wajib dikeluarkan oleh wajib zakat (muzakki). Zakat yang dibayarkan oleh muzakki jika sudah terpenuhi nisab serta haul dari harta yang akan dizakatkan bagi wajib zakat. Poin penting dalam sumber dan penggunaan dana zakat terdapat sumber serta penggunaan dana zakat selama periode tertentu. Selain itu juga ditunjukkan saldo dana zakat serta jumlah dana zakat yang disalurkan kepada penerima zakat. Hal penting yang diketahui bahwasanya dana zakat tidak diperkenankan untuk menutupi penyisihan kerugian aset produktif(Suharto 2020)

\section{Laporan Catatan Atas Laporan Keuangan}

Catatan atas laporan keuangan ini memberikan informasi terhadap tambahan 
informasi dalam penyajian laporan keuangan. Hal ini ditujukan supaya pengguna laporan keuangan memperoleh informasi yang tepat mengenai faktor yang mempengaruhi laporan pada perusahaan tertentu (Isnani Yuli Andiri 2011)

\section{METODE PENELITIAN}

Teknik analisis data yang gunakan dalam penelitian ini adalah analisis deskriptif kualitatif. Adapun analisis deskriptif ini menjelaskan bentuk laporan keuangan yang ada di lembaga keuangan syariah, namun dalam penulisan ini penulis menfokuskan kepada dua laporan saja yaitu laporan sumber dan kegunaan dana qardhul hasan serta laporan sumber dan kegunaan dana zakat.

\section{HASIL DAN PEMBAHASAN}

Lembaga keuangan memenuhi kewajibannya dalam membuat laporan keuangan untuk melihat serta menentukan keputusan yang akan diambil untuk periode yang akan datang. Sebagaimana diketahui bahwa laporan keuangan merupakan suatu pertanggungjawaban seorang manager dalam mengelola keuangan dana di salah satu lembaga keuangan. Di lembaga keuangan syari `ah, laporan keuangan tidak hanya menginformasikan sumber dana serta penggunaan dana yang secara umum saja sebagaimana yang ada di laporan keuangan konvensional. Tapi pada lembaga keuangan syariah, penyajian laporan keuangan disajikan berdasarkan fungsi dan kegunaanya.
Sebagaimana diketahui, bahwa di lembaga keuangan syari`ah, terdapat dua bentuk laporan yang yang menginformasikan penggunaan dana dilembaga keuangan syariah yang dikategorikan kepada dana social, diantaranya yaitu:

\section{Sumber Dan Penggunaan Dana Qardhul Hasan}

Dana kebajikan merupakan dana sosial diluar zakat yang berasal dari masyarakat yang dikelola oleh bank syari`ah. Dana kebajikan ini biasanya disebut dengan dana qardh. Sumber dana kebajikan ini terdiri dari infak, sedekah hasiil pengelolaan wakaf sesuai dengan perundangan yang berlaku, pengembalian dana kebajikan produktif, denda, pendapatan non halal, serta sumbangan/hibah. Dana kebajikan ini digunakan untuk dana kebajikan produktif, sumbangan dan penggunaan lainnya untuk kepentingan umum (Suharto 2020).

Sumber dan penggunaan dana pada Lembaga keuangan syariah, ada yang menyajikan sebagai sumber dan penggunaan dana qardh ada juga yang menyajikan laporan sumber dan penggunaan dana kebajikan. Namun komponen yang terdapat pada laporan ini akan sama, hanya saja pada sebagian lembaga memberikan perbedaan nama namun tujuannya sama yaitu memberikan informasi terhadap sumber serta penggunaan dana kebajikan yang berasal dari infak, sedekah dan hasil dari pengelolaan wakaf. Laporn ini digunakan untuk memberikan informasi supaya 
pengguna laporan keuangan dapat (Anam 2017). Adapun, bentuk penyajian melakukan evaluasi terhadap bank dalam laporan sumber dan penggunaan dalam mengelola dana kebajikan. dana kebajikan ini yaitu:

Tabel 1

\begin{tabular}{|c|c|}
\hline Uraian & Jumlah \\
\hline 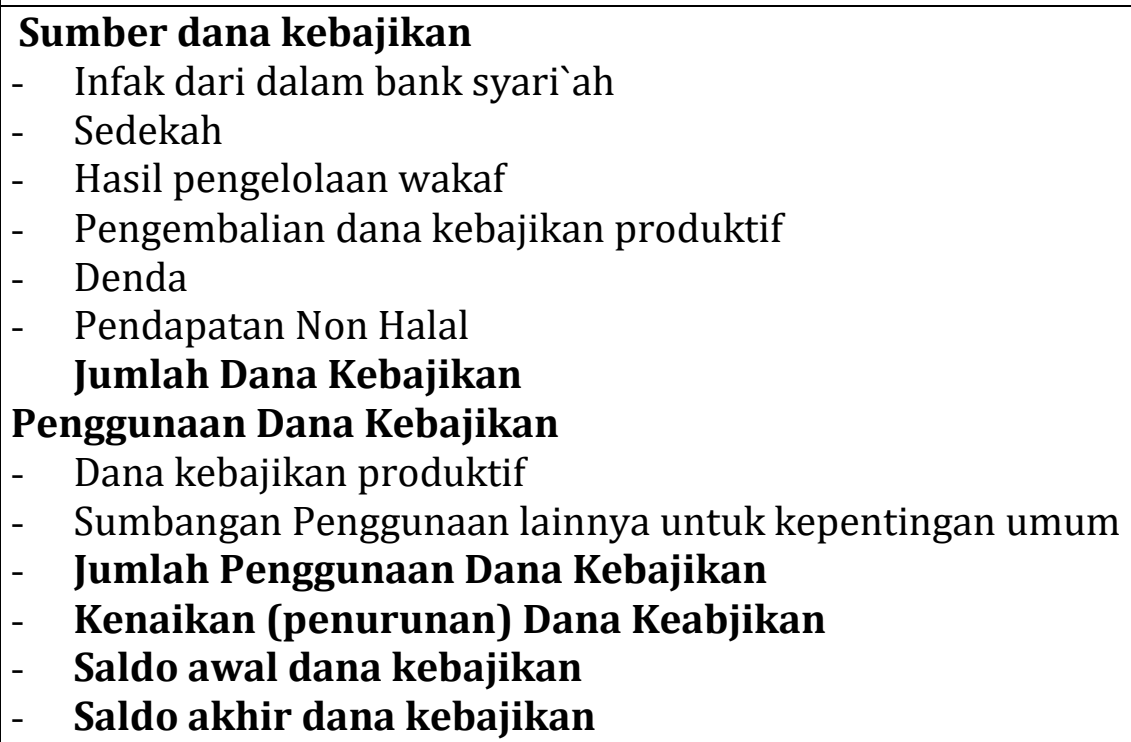 & $\begin{array}{c}\text { Xxx } \\
\text { Xxx } \\
\text { xxx } \\
\text { xxx } \\
\text { xxx } \\
\text { xxx } \\
\text { xxx } \\
\\
(x x x) \\
(x x x) \\
(x x x) \\
(\mathbf{x x x}) \\
\mathbf{x x x} \\
\mathbf{x x x}\end{array}$ \\
\hline
\end{tabular}

Berdasarkan tabel di atas, diketahui adanya sumber dana kebajikan itu berasal dari denda, dimana denda ini diperoleh dari nasabah yang telat dalam melakukan pembayaran angsuran, sehingga bank syari'ah akan memasukkan dana denda itu kepada sumber dana kebajikan bukan dimasukkan kepada pendapatan. Selain itu juga terdapat sumber dana kebajikan ini berasal dari pendapatan non halal. Sebagaimana diketahui bahwasanya pendapatan non halal ini berasal dari bunga bank yang terjadi akibat adanya transaksi yang terjadi antara bank syariah dengan bank konvensional (Harkaneri and Reflisa 2018). Dalam hal ini bunga bank tersebut akan dikelompokkan kepada laporan sumber dana kebajikan sebagai pendapatan non halal.
Selanjutnya, penggunaan dana kebajikan di bank syariah ini diperuntukkan untuk dana sosial, sebagaimana diketahui salah satunya itu diberikan dalam bentuk sumbangan, dan juga berupa dana kebajikan produktif dalam meningkatkan perekonomian masyarkat.

\section{Laporan Sumber Dan Penggunaan Dana Zakat}

Laporan sumber dan penyaluran dana zakat merupakan laporan yang menunjukkan sumber serta penyaluran dana zakat di suatu lembaga keuangan syari`ah dalam periode tertentu. Pembayaran dana zakat dilaksanakan jika nisab serta haulnya sudah terpenuhi dan kemudian disalurkan kepada penerima zakat atau asnaf delapan. Adapun dana zakat yang ada dilembaga keuangan syariah berasal dari pemilik bank yang dihitung berdasarkan laba neto sebelum pajak

154 | Penyusunan dan Penyajian Laporan Keuangan di Lembaga Keuangan Syari 'ah 
satu periode. Selain itu juga terdapat dana zakat dari pihak luar, misalnya dari nasabah ataupun masyarakat yang bukan nasabah dari bank tersebut (Anam 2017). Berikut ditampilkan bagaimana penyusunan serta penyusunan laporan keuangan sumber dan penggunaan dana zakat di lembaga keuangan syariah:

Tabel 2

\begin{tabular}{|l|c|}
\hline \multicolumn{1}{|c|}{ Uraian } & Jumlah \\
\hline Sumber Dana Zakat: & \\
- Zakat berasal dari pihak internal dan eksternal bank syari'ah & $\mathrm{xxx}$ \\
- Zakat berasal dari masyarakat & $\mathrm{xxx}$ \\
Jumlah sumber dana zakat & $\mathbf{x x x}$ \\
Penggunaan Dana Zakat: & \\
- Fakir & $\mathrm{xxx}$ \\
- $\quad$ Miskin & $\mathrm{xxx}$ \\
- Panitia pengumpul zakat & $\mathrm{xxx}$ \\
- Orang yang baru masuk Islam & $\mathrm{xxx}$ \\
- Orang yang terlilit hutang (gharim) & $\mathrm{xxx}$ \\
- Riqab & $\mathrm{xxx}$ \\
- Fiisabilillah & $\mathrm{xxx}$ \\
- Ibnu Sabil & $\mathrm{xxx}$ \\
Jumlah Penggunaan dana zakat & $\mathbf{x x x}$ \\
Kenaikan (penurunan) dana zakat & $\mathbf{x x x}$ \\
Saldo awal dana zakat & $\mathbf{x x x}$ \\
Saldo akhir dana zakat & $\mathbf{x x x}$ \\
\hline
\end{tabular}

Berdasarkan tabel di atas, maka dapat diketahui bahwasanya dapat diperhatikan bahwasanya pada laporan ini terdapat sumber dana zakat di lembaga keuanagn syari ah berasal dari pihak internal bank syari'ah dan juga pihak external yaitu masyarakat yang bukan nasabah bank syari'ah sendiri, namun membayarkan zakatnya ke bank syari’ah. Adapun penggunaan dana zakat di bank syari`ah itu disalurkan kepada mustahik penerima zakat yang kriterianya sudah ditentukan dalam al Qur`an.

\section{PENUTUP}

Berdasarkan informasi dan penjabaran penulis pada artikel ini, maka dapat disimpulkan bahwasanya di lembaga keuangan syari'ah terdapat laporan keuangan yang memiliki tujuan untuk memberikan informasi terhadap sumber dan penggunaan dana yang diperuntukkan untuk sosial. Sebagaimana diketahui laporan tersebut yaitu sumber dan penggunaan dana qardhuul hasan dan juga laporan keuangan sumber dan penggunaan dana zakat.

Sumber dan penggunaan dana qardhul hasan bersumber dari dana infak, sedekah serta hasil dari pengelolaan dana wakaf dan juga terdapat pendapatan non halal. Sementara itu pada laporan keuangan sumber dan penggunaan dana zakat berasal dari dana zakat yang diperoleh 
dari pihak internal lembaga keuangan syari'ah dan pihak eksternal dari masyarkaat bukan nasabah bank syari'ah tersebut. Penulis memberikan masukan kepada peneliti selanjutnya untuk dapat melakukan analisis perbedaan penyajian laporan keuangan di lembaga keuangan konvensional dengan laporan keuangan di lembaga keuangan syariah.

\section{DAFTAR KEPUSTAKAAN}

Agil, Antung, and Ibnu Giri. 2016. "ANALISIS FAKTOR-FAKTOR YANG MEMPENGARUHI KINERJA KEUANGAN BANK YANG TERDAFTAR DI." 4(1): 26-39.

Amah, Nik. 2013. "Bank Syariah Dan UMKM Dalam Menggerakkan Roda Perekonomian Indonesia: Suatu Kajian Literatur." ASSETS: Jurnal Akuntansi dan Pendidikan 2(21): 48-54.

Anam, Mohammad Khoirul. 2017. "Penerapan PSAK 101 Pada Laporan Dana Zakat Dan Dana Kebajikan." Misykat Al Anwar Vol 28(No 2). http://jurnal.faiumj.ac.id/index.php/MaA16/articl e/view/35.

Diana Fajarwati, Djoko Sambodo. 2010. "PENYUSUNAN DAN PENYAJIAN LAPORAN KEUANGAN PADA LEMBAGA KEUANGAN SYARIAH." Jurnal Riset Akuntansi dan Komputerisasi 2: 15-37.

Harkaneri, and Hana Reflisa. 2018. "Pendapatan Non Halal Sebagai Sumber Dan Penggunaan Qardhul Hasan Dalam Perspektif Islam." Rumpun Ekonomi Syariah 1(2): 118.

Ilyas, Rahmat. 2016. "Kerangka Dasar Penyusunan Dan Penyajian
Laporan Keuangan Syariah." Asy Syar'lyyah: Jurnal Ilmu Syari'Ah Dan Perbankan Islam 1(1): 19-41.

Isnani Yuli Andiri, Norsain. 2011. "Pendapatan Bagi Hasil Dan Penyajian Laporan Keuangan Pada Bank Syariah (Studi Kasus Pada PT. BPRS Bhakti Sumekar Sumenep)." IV(1): 1-13.

Kadarningsih, Ana. 2017. "Penyajian Akuntansi Qardhul Hasan Dalam Laporan Keuangan Perbankan Syariah." JESI (Jurnal Ekonomi Syariah Indonesia) 7(1): 32.

Matnin. 2016. "Kinerja Dan Kesehatan Bank Islam." Jurnal DINAR Ekonomi Syariah 1(1): 1-9.

Nandasari, Mariska Putri. 2014. "Analisis Penerapan Laporan Keuangan Berbasis Standar Dian Nuswantoro University , Jornal Accounting." Jornal Accounting: 123.

Putri, Cut Emylia, Robin Jonathan, and Elfreda Aplonia Lau. 1998. "Analisis Kinerja Keuangan Bank Mandiri Konvensional Dan Bank Bank Mandiri Syariah Cabang Sangatta." (10): 1-16.

Suharto, T. 2020. "ANALISIS LAPORAN KEUANGAN BANK SYARI'AH TERHADAP KEPUTUSAN NASABAH MEMILIH BANK." Jurnal Inovasi Penelitian. https://stpmataram.ejournal.id/JIP/article/view/162.

Sutarti, Enjang Tachyan, and Adilah Saesar. 2012. "Evaluasi Atas Penerapan Pernyataan Standar Akuntansi Keuangan 101 Dalam Kaitannya Dengan Kewajaran Penyajian Laporan Keuangan Pada Pt. Bank Jabar Banten Syariah." Jurnal Ilmiah Ranggagading 12(2): 102-9. 